\title{
ANALISIS PERENCANAAN PAJAK PENGHASILAN ATAS PENGEMBANGAN INVESTASI BIDANG PROPERTI
}

\author{
Natalia Kartika ${ }^{a}$ \\ Heru Tjaraka ${ }^{b}$ \\ ${ }^{a}$ Sekolah Pascasarjana Universitas Airlangga ${ }^{\mathrm{b}}$ Fakultas Ekonomi dan Bisnis Universitas Airlangga \\ Email: natalia.kartika7@yahoo.com ${ }^{a}$; heru_tjaraka@yahoo.co.id ${ }^{b}$
}

ARTICLE HISTORY

Received:

9 Februari 2018

Revised

5 March 2018

Accepted:

21 March 2018

Online available:

30 Mei 2018

Keywords :

income tax, tax planning, joint

operation, and limited liability company.

\begin{abstract}
Business investment in property is very promising and could be an asset in the future because the price of land and buildings continue increasing. Many entrepreneurs are interested in investing in property but it is not an easy thing. For entrepreneurs who have investment opportunities but do not have sufficient funds or assets or otherwise, can be empowered by getting its business partners for mutual investment through the establishment of a new business entity.

The establishment of business entities is certainly not free from income tax aspects. Income taxes are expenses that reduce income earned by entrepreneurs. Therefore tax planning is necessary in order to save costs without violating applicable regulations. Selection in the establishment of business entities is one way to do tax planning. The right selection in establishment of business entities can give tax savings without violating applicable regulations.

This study aims to determine the income tax planning analysis of the development of property investment, if done with the establishment of joint operation (JO) or forming a Limited Liability Company (PT). This study used a qualitative research approach with the strategy used in this research is a case study on PT X and PT Y. The results of the analysis and discussion shows that the burden of income tax to be paid by PT X and PT $Y$ will be lower when it is done with the establishment of a joint operation (JO) than if it is done with the establishment of a Limited Liability Company (PT).
\end{abstract}




\section{LATAR BELAKANG}

Bagi para pebisnis selaku Wajib Pajak yang ingin mengembangkan bisnis dan berorientasi pada laba, pasti akan berusaha melakukan banyak cara untuk melakukan efisiensi biaya termasuk didalamnya adalah biaya pajak. Meskipun demikian cepatnya perubahan peraturan pajak yang berlaku dan adanya peraturan baru yang terus menerus dikeluarkan oleh Pemerintah, tentu masih terdapat celah untuk melakukan efisiensi biaya pajak tanpa melanggar peraturan pajak yang berlaku. Hal ini dikenal dengan istilah perencanaan pajak.

Tindakan pengusaha dalam melakukan perencanaan pajak dapat dimulai sejak pemilihan bentuk usaha. Bentuk usaha lazimnya dibagi menjadi tiga yaitu perseorangan, badan usaha, dan Bentuk Usaha Tetap. Seperti yang telah disebutkan sebelumnya bahwa pemanfaatan ketentuan perpajakan dapat dimulai sejak pemilihan bentuk usaha, maka ketentuan perpajakan tersebut dapat digunakan sebagai salah satu bahan pertimbangan mengapa suatu bentuk usaha dipilih untuk merealisasikan kegiatan usaha.

Seperti yang diketahui sekarang ini bisnis investasi bidang properti sangat menjanjikan dan dapat menjadi aset masa depan mengingat harga tanah dan bangunan yang terus meningkat. Meskipun kegaiatan usaha bidang properti menjadi sebuah kegiatan usaha yang sangat diminati, tentu bukan hal yang mudah untuk menjalankan kegiatan usaha tersebut. Yang sering terjadi saat ini adalah beberapa pebisnis tidak memiliki tanah yang cukup luas untuk menjalankan kegiatan usaha bidang properti namun memiliki modal yang besar untuk melakukan investasi, begitu pula ada pebisnis yang hanya memiliki tanah yang sangat luas namun tidak memiliki modal yang cukup untuk melakukan investasi bidang properti.

Hal inilah yang ditangkap sebagai peluang oleh PT $X$ dan PT $Y$ untuk mengembangkan kegiatan usaha bidang properti. Bekerjasama dengan mitra usaha untuk saling berinvestasi dapat menjadi hal yang saling menguntungkan. Bentuk kerjasama yang dipilih tentu tidak lepas dari aspek perpajakannya masing-masing.

Berdasarkan peluang kerjasama antara PT $X$ dan PT $Y$ untuk mengembangkan kegiatan usaha bidang properti tersebut maka topik yang digunakan dalam penelitian ini adalah tentang analisis perencanaan pajak penghasilan atas pengembangan investasi bidang properti. Kerjasama yang dilakukan melalui pemilihan dua alternatif yaitu

pembentukan badan usaha baru dalam bentuk kerjasama operasi (KSO) atau pembentukan badan usaha baru dalam bentuk Perseroan Terbatas (PT). Kondisi saat ini PT $X$ hanya memiliki tanah namun tidak memiliki modal yang cukup sedangkan PT $Y$ memiliki modal yang cukup tetapi tidak memiliki tanah untuk mengembangkan investasi bidang properti. Alternatif pertama adalah melalui pembentukan kerjasama operasi (KSO) dimana PT X akan menyetorkan tanah dan PT Y akan menyetorkan dana sebagai modal KSO. Kemudian KSO akan melakukan pembangunan perumahan yang nantinya 
akan dijual langsung kepada konsumen akhir. Atas hasil keuntungan penjualan perumahan tersebut akan dibagikan kepada para pendiri KSO yaitu PT X dan PT Y dalam bentuk bagi hasil. Alternatif kedua adalah melalui pembentukan badan usaha baru berbentuk Perseroan Terbatas (PT). PT $X$ akan menyetorkan tanah dan PT Y akan menyetorkan dana sebagai modal pendirian perusahaan yang baru. Kemudian PT baru tersebut akan melakukan pembangunan properti yang nantinya akan dijual langsung kepada konsumen akhir. Atas hasil keuntungan penjualan properti tersebut yang menjadi laba PT baru akan dibagikan kepada pemilik modal yaitu PT X dan PT Y dalam bentuk dividen. Akan dilakukan analisis terhadap perencanaan pajak penghasilan atas pengembangan investasi bidang properti melalui kedua alternatif seperti yang telah disebutkan sebelumnya. Kemudian dari kedua alternatif tersebut, mana yang akan menghasilkan efisiensi biaya pajak penghasilan yang paling tinggi sehingga dapat menguntungkan bagi PT X maupun PT Y selaku Wajib Pajak dalam melakukan efisiensi biaya tanpa melanggar peraturan perundang-undangan perpajakan yang berlaku. Pemilihan atas kedua alternatif agar dapat menghasilkan efisiensi biaya pajak penghasilan yang paling tinggi merupakan salah satu cara untuk melakukan perencanaan pajak.

\section{TINJAUAN PUSTAKA}

Kerjasama Operasi (KSO)

Dalam Pernyataan Standar Akuntansi Keuangan (PSAK) Nomor 39 sebagaimana telah diperbaharui dengan ED PPSAK Nomor 11 tentang Akuntansi Kerja Sama Operasi dijelaskan bahwa Kerjasama Operasi (KSO) adalah perjanjian antara dua pihak atau lebih, dimana masing-masing sepakat untuk melakukan suatu usaha bersama dengan menggunkan aset dan atau hak usaha yang dimiliki dan secara bersama menanggung risiko usaha tersebut. Lebih lanjut, menurut Surat Dirjen Pajak Nomor S-323/PJ.42/1989 tentang Masalah Perpajakan Bagi Joint Operation menyebutkan bahwa pengertian Kerjasama Operasi (KSO) yaitu perkumpulan dua badan atau lebih yang bergabung untuk menyelesaikan suatu proyek.

\section{A. Kewajiban Perpajakan}

Berdasarkan UU PPh Pasal 2 ayat (1) huruf b KSO tidak termasuk dalam pengertian subjek pajak badan. Meskipun KSO bukan merupakan subjek pajak, namun KSO wajib mendaftarkan diri untuk memperoleh Nomor Pokok Wajib Pajak (NPWP). Kewajiban KSO mendaftarkan diri untuk memperoleh NPWP adalah semata-mata hanya untuk memenuhi kewajiban perpajakan sebagai pemotong dan/atau pemungut pajak sesuai ketentuan peraturan perundang-undangan perpajakan. KSO tidak berkewajiban untuk 
membayar dan/atau melaporkan PPh Pasal 25 serta PPh Pasal 29 seperti Wajib Pajak sebagaimana dimaksud dalam UU KUP.

B. Aspek Pajak Penghasilan atas Penyertaan Modal

Dikarenakan bentuk KSO hanya bersifat sementara dan modal KSO tidak terbagi atas saham, maka atas penyertaan modal oleh PT $\mathrm{X}$ dalam bentuk tanah kepada KSO tidak termasuk dalam pengertian pengalihan hak sebagaimana dimaksud dalam PP Nomor 48 Tahun 1994 jo. PP Nomor 71 Tahun 2008 sehingga tidak terutang pajak penghasilan. Lebih lanjut, dalam Latar Belakang juga disebutkan bahwa PT Y akan melakukan penyertaan modal dalam bentuk uang kepada KSO. Penyertaan modal tersebut bagi PT Y merupakan bentuk investasi sehingga tidak terutang pajak penghasilan.

Adapun bagi KSO penerimaan modal dari PT $\mathrm{X}$ dalam bentuk tanah dan PT $\mathrm{Y}$ dalam bentuk uang tidak terutang pajak penghasilan. Hal ini sesuai dengan yang telah dijelaskan sebelumnya bahwa KSO bukan merupakan subjek pajak sebagaimana dimaksud dalam UU PPh Pasal 2 ayat (1) huruf b.

C. Aspek Pajak Penghasilan atas Pembangunan Properti

Dalam proses pembangunan pihak KSO menggunakan jasa konstruksi. Atas pembayaran penggunaan jasa konstruksi yang merupakan bagian dari Nilai Kontrak Jasa Konstruksi, KSO wajib melakukan pemotongan PPh Pasal 4(2) sesuai dengan ketentuan yang berlaku yaitu PP No. 51 Tahun 2008 jo. PP No. 40 Tahun 2009. PPh sebagaimana dimaksud akan mengurangi jumlah pembayaran dari KSO kepada pihak penyedia jasa konstruksi. Dengan demikian PPh tersebut bukan merupakan beban pajak yang mengurangi laba bersih KSO.

D. Aspek Pajak Penghasilan atas Penjualan Properti

Pajak penghasilan atas penghasilan dari pengalihan hak atas tanah dan/atau bangunan diatur dalam PP Nomor 48 Tahun 1994 jo. PP Nomor 71 Tahun 2008. Penghasilan atas penjualan properti terutang PPh Final dengan tarif 5\% dari jumlah bruto nilai pengalihan hak atas tanah dan/atau bangunan. Nilai pengalihan hak sebagaimana dimaksud adalah nilai yang tertinggi antara nilai berdasarkan Akta Pengalihan Hak dengan Nilai Jual Objek Pajak tanah dan/atau bangunan yang bersangkutan.

Ditegaskan dalam Surat Edaran Direktur Jenderal Pajak Nomor SE-30/PJ/2013 Bagian E huruf e dan $f$ bahwa:

Dalam hal terdapat dua atau lebih Wajib Pajak yang usaha pokoknya melakukan pengalihan hak atas tanah dan/atau bangunan bekerja sama membentuk Kerja Sama Operasi (KSO) / Joint Operation (JO) melakukan pengalihan hak atas tanah dan/atau bangunan maka PPh Final atas pengalihan hak atas tanah dan/atau bangunan dibayar oleh masing-masing anggota KSO sesuai dengan bagian penghasilan yang diterima masing-masing anggota KSO. Dalam hal PPh Final sebagaimana dimaksud pada huruf e telah dibayar dengan menggunakan Surat 
Setoran Pajak (SSP) atas nama KSO atau salah satu anggota KSO maka SSP tersebut dipindahbukukan ke masing-masing anggota KSO sesuai dengan bagian penghasilan yang diterima masing-masing anggota KSO.

E. Aspek Pajak Penghasilan atas Laba Bersih

Seperti yang telah dijelaskan sebelumnya bahwa KSO bukan merupakan subjek pajak. Dengan demikian maka KSO tidak berkewajiban utnuk menyampaikan laporan dan membayar PPh Pasal 25 serta PPh Pasal 29. Pengenaan PPh Badan tetap dikenakan atas penghasilan yang diperoleh pada masing-masing badan yang bergabung tersebut sesuai dengan porsi/bagian pekerjaan atau penghasilan yang diterimanya. Dengan demikian dapat disimpulkan bahwa atas laba bersih yang diterima oleh KSO tidak dikenakan pajak penghasilan. Namun demikian ketika laba bersih tersebut dibagikan kepada masingmasing badan yang bergabung dalam KSO, laba bersih tersebut akan menambah laba bersih masing-masing badan yang bergabung dalam KSO dan akan dikenakan pajak penghasilan sesuai dengan ketentuan yang berlaku.

Bagi PT X dan PT Y selaku anggota KSO yang menerima pembagian laba bersih KSO sesuai dengan porsi/bagian pekerjaan atau penghasilan yang diterimanya, laba bersih tersebut akan ditambahkan dalam laba bersih masing-masing perusahaan dan akan dikenakan PPh Badan sesuai dengan kententuan yang berlaku yaitu berdasarkan UU PPh Pasal 16 ayat (1) dan Pasal 17 ayat (2a).

Selain itu, bagi Wajib Pajak badan dalam negeri dengan peredaran bruto sampai dengan Rp 50.000.000.000,00 mendapat fasilitas berupa pengurangan tarif sebesar 50\% dari tarif pasal 17 ayat (2a) yang dikenakan atas Penghasilan Kena Pajak dari bagian peredaran bruto sampai dengan $\mathrm{Rp} 4.800 .000 .000,00$ (empat miliar delapan ratus juta rupiah). Hal ini sejalan dengan UU PPh Pasal 31E ayat (1).

Badan (Perseroan Terbatas)

Berdasarkan UU Nomor 40 Tahun 2007 tentang Perseroan Terbatas Pasal 1 angka 1 disebutkan bahwa Perseroan Terbatas, yang selanjutnya disebut perseroan, adalah

badan hukum yang merupakan persekutuan modal, didirikan berdasarkan perjanjian, melakukan kegiatan usaha dengan modal dasar yang seluruhnya terbagi dalam saham dan memenuhi persyaratan yang ditetapkan dalam undangundang ini serta peraturan pelaksanaannya.

A. Kewajiban Perpajakan

Perseroan Terbatas (PT) merupakan subjek pajak badan sebagaimana dimaksud dalam UU PPh Pasal 2 ayat (1) huruf b. Perseroan Terbatas (PT) wajib mendaftarkan diri untuk memperoleh NPWP. Kewajiban perpajakan PT adalah sebagai pembayar pajak, 
pemotong dan/atau pemungut pajak sesuai ketentuan peraturan perundang-undangan perpajakan, termasuk melaporkan SPT Tahunan PPh Badan.

B. Aspek Pajak Penghasilan atas Penyertaan Modal

Seperti yang telah dijelaskan pada bagian Latar Belakang, PT X akan melakukan penyertaan modal dalam bentuk tanah kepada PT baru. Atas penyertaan modal dalam bentuk tanah dari PT X kepada PT baru terutang pajak penghasilan dikarenakan terjadi pengalihan hak sebagaimana dimaksud dalam PP Nomor 48 Tahun 1994 jo. PP Nomor 71 Tahun 2008. Lebih lanjut, dalam Latar Belakang juga disebutkan bahwa PT Y akan melakukan penyertaan modal dalam bentuk uang kepada KSO. Penyertaan modal tersebut bagi PT Y merupakan bentuk investasi sehingga tidak terutang pajak penghasilan. Sedangkan penerimaan modal baik dalam bentuk tanah maupun uang yang diterima oleh PT baru tidak terutang pajak penghasilan sebagaimana dimaksud dalam UU PPh Pasal 4 ayat (3).

C. Aspek Pajak Penghasilan atas Pembangunan Properti

Perlakuan Pajak Penghasilan atas Pembangunan Properti yang dilakukan oleh PT baru sama seperti yang telah dijelaskan dalam bagian KSO.

D. Aspek Pajak Penghasilan atas Penjualan Properti

Pajak penghasilan atas penghasilan dari pengalihan hak atas tanah dan/atau bangunan diatur dalam PP Nomor 48 Tahun 1994 jo. PP Nomor 71 Tahun 2008. Penghasilan atas penjualan properti terutang PPh Final dengan tarif $5 \%$ dari jumlah bruto nilai pengalihan hak atas tanah dan/atau bangunan. Nilai pengalihan hak sebagaimana dimaksud adalah nilai yang tertinggi antara nilai berdasarkan Akta Pengalihan Hak dengan Nilai Jual Objek Pajak tanah dan/atau bangunan yang bersangkutan.

E. Aspek Pajak Penghasilan atas Laba Bersih

Atas Laba Bersih PT baru akan dikenakan pajak penghasilan berdasarkan UU PPh Pasal 16 ayat (1) dan Pasal 17 ayat (2a).

Dikarenakan penghasilan PT baru berupa penjualan perumahan telah dikenakan PPh Final, maka seharusnya tidak terdapat pajak penghasilan badan yang terutang sebagaimana dimaksud dalam UU PPh Pasal 16 ayat (1) dan Pasal 17 ayat (2a). Beban pajak penghasilan yang mengurangi laba bersih PT baru adalah PPh Final yang telah dibayarkan atas penjualan perumahan seperti yang telah dijelaskan sebelumnya.

F. Aspek Pajak Penghasilan atas Dividen

Atas laba bersih yang diterima oleh PT baru akan dibagikan kepada pemegang saham dalam bentuk dividen. Atas dividen yang diterima oleh Wajib Pajak ada yang merupakan objek pajak penghasilan dan ada yang dikecualikan dari objek pajak sebagaimana diatur dalam UU PPh Pasal 4 ayat (1) huruf $g$ dan Pasal 4 ayat (3) huruf $f$. 
Lebih lanjut berdasarkan UU Nomor 40 Tahun 2007 tentang Perseroan Terbatas dijelaskan bahwa pembagian dividen atas laba bersih PT Baru yang dilakukan bukan atas seluruh jumlah laba bersih PT baru namun harus dikurangkan cadangan sebagaimana dimaksud dalam UU Nomor 40 Tahun 2007 tentang Perseroan Terbatas

\section{METODE PENELITIAN)}

Metode penelitian yang digunakan dalam penulisan ini adalah pendekatan penelitian kualitatif dengan menggunakan studi kasus pada PT X dan PT Y. Tahap-tahap penelitian menggunakan studi kasus sebagaimana yang dipaparkan oleh Yin (2013) adalah sebagai berikut:

1. Desain penelitian studi kasus

Menurut Yin (2013: 29) untuk studi kasus terdapat beberapa komponen desain penelitian yang sangat penting yaitu:

a. Pertanyaan penelitian

Strategi studi kasus merupakan strategi yang paling cocok untuk pertanyaan "bagaimana" dan "mengapa". Dengan demikian pertanyaan dalam penelitian ini telah sesuai dengan penggunaan strategi studi kasus dikarenakan pertanyaan penelitian berkaitan dengan "bagaimana".

b. Proposisi

Dalam penelitian proposisi adalah sesuatu yang diteliti. Proposisi dalam penelitian ini adalah mengenai analisis perencanaan pajak penghasilan atas pengembangan investasi bidang properti.

c. Unit analisis

Komponen ini berkaitan dengan kasus dalam penelitian yang bersangkutan. Dalam penelitian ini terdapat beberapa unit analisis yaitu:

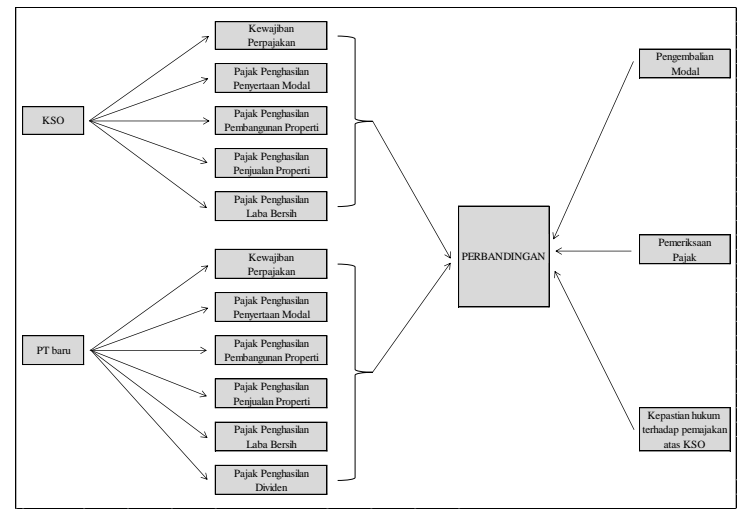

Gambar 1. RERANGKA KONSEPTUAL

Sumber: DATA DIOLAH 


\section{Pelaksanaan Pengumpulan Data}

Setelah ditentukan desain penelitian sudi kasus maka langkah berikutnya adalah menyelenggarakan studi kasus yaitu pelaksanaan pengumpulan bukti atau data. Menurut Yin (2013: 101) data untuk keperluan studi kasus bukti atau data dapat berasal dari beberapa sumber diantaranya adalah dokumen dan wawancara seperti yang digunakan dalam penelitian ini.

3. Analisis Bukti Studi Kasus

Menurut Yin (2013: 133) analisis bukti (data) terdiri atas pengujian, pengkategorian, pentabulasian, ataupun pengombinasian kembali bukti-bukti untuk menjawab proposisi penelitian. Lebih lanjut menurut Yin (2013: 133) menganalisis bukti studi kasus adalah hal yang sulit dikarenakan strategi dan tekniknya belum teridentifikasikan secara memadai di masa lalu. Oleh karena itu Yin menjelaskan terdapat tiga teknik analisis yang dapat digunakan yaitu penjodohan pola, pembuatan penjelasan, dan analisis deret waktu.

\section{HASIL PENELITIAN DAN ANALISA}

Kerjasama Operasi (KSO)

A. Kewajiban Perpajakan

Berdasarkan UU PPh Pasal 2 ayat (1) huruf b KSO tidak termasuk dalam pengertian subjek pajak badan. Meskipun KSO bukan merupakan subjek pajak, namun KSO wajib mendaftarkan diri untuk memperoleh Nomor Pokok Wajib Pajak (NPWP). Kewajiban KSO mendaftarkan diri untuk memperoleh NPWP adalah semata-mata hanya untuk memenuhi kewajiban perpajakan sebagai pemotong dan/atau pemungut pajak sesuai ketentuan peraturan perundang-undangan perpajakan. KSO tidak berkewajiban untuk membayar dan/atau melaporkan PPh Pasal 25 serta PPh Pasal 29 seperti Wajib Pajak sebagaimana dimaksud dalam UU KUP.

B. Aspek Pajak Penghasilan atas Penyertaan Modal

Penyetoran modal berupa tanah dari PT $\mathrm{X}$ dan berupa dana dari PT Y kepada KSO, keduanya tidak terdapat pajak penghasilan yang terutang.

\begin{tabular}{|c|r|r|r|}
\hline Keterangan & \multicolumn{1}{|c|}{ PT X } & \multicolumn{1}{c|}{ PT Y } & \multicolumn{1}{c|}{ KSO } \\
\hline Pajak Penghasilan & 0 & 0 & 0 \\
\hline
\end{tabular}

Gambar 2. PPh Setoran Modal kepada KSO

Sumber: DATA DIOLAH 


\section{Aspek Pajak Penghasilan atas Pembangunan Properti}

Atas penggunaan jasa konstruksi tersebut KSO wajib melakukan pemotongan PPh sesuai dengan ketentuan yang berlaku. PPh Final yang dipotong tersebut akan mengurangi jumlah pembayaran dari KSO kepada pihak penyedia jasa konstruksi.

\section{Aspek Pajak Penghasilan atas Penjualan Properti}

Berdasarkan data-data penjualan unit perumahan yang telah disebutkan diatas maka berikut ini adalah penghitungan jumlah penghasilan atas penjualan unit perumahan yang diterima oleh KSO dan PPh Final-nya:

\begin{tabular}{|l|lr|}
\hline \multicolumn{1}{|c|}{ Keterangan } & \multicolumn{2}{c|}{ KSO } \\
\hline Jumlah Unit & $\mathrm{R}$ & 2.094 unit \\
\hline Harga Jual / Unit & $\mathrm{Rp}$ & 495.000 .000 \\
\hline Total Penjualan & $\mathrm{Rp}$ & 1.036 .530 .000 .000 \\
\hline Total PPh Final 5\% & 51.826 .500 .000 \\
\hline
\end{tabular}

Gambar 3. Penghasilan Penjualan Properti dan PPh Final Sumber: DATA DIOLAH

Dikarenakan yang melakukan pengalihan hak atas tanah dan/atau bangunan adalah KSO maka PPh Final atas pengalihan hak atas tanah dan/atau bangunan dibayar oleh masingmasing anggota KSO sesuai dengan bagian penghasilan yang diterima masing-masing anggota KSO.

\begin{tabular}{|l|c|c||}
\hline \multicolumn{1}{|c|}{ Keterangan } & Kepemilikan & \multicolumn{2}{|c|}{ PPh Final } \\
\hline KSO & --- & $\operatorname{Rp} 51.826 .500 .000$ \\
\hline PT X & $65 \%$ & $\operatorname{Rp} 33.687 .225 .000$ \\
\hline PT Y & $35 \%$ & $\operatorname{Rp~} 18.139 .275 .000$ \\
\hline
\end{tabular}

Gambar 4. PPh Final Penjualan Perumahan Sumber: DATA DIOLAH

\section{E. Aspek Pajak Penghasilan atas Laba Bersih}

Atas laba bersih yang diterima oleh KSO langsung dibagikan kepada masing-masing badan yang bergabung dalam KSO. Sehingga laba bersih tersebut akan menambah laba bersih masing-masing badan yang bergabung dalam KSO dan akan dikenakan pajak penghasilan sesuai dengan ketentuan yang berlaku.

\begin{tabular}{|l|c|c|}
\hline \multicolumn{1}{|c|}{ Keterangan } & Kepemilikan & Laba Bersih \\
\hline KSO & --- & $\operatorname{Rp} 233.018 .372 .093$ \\
\hline PT X & $65 \%$ & $\operatorname{Rp~} 151.461 .941 .860$ \\
\hline PT Y & $35 \%$ & $\operatorname{Rp~} 81.556 .430 .233$ \\
\hline
\end{tabular}

Gambar 5. Pembagian Laba Usaha KSO

Sumber: DATA DIOLAH 


\section{Badan (Perseroan Terbatas)}

\section{A. Kewajiban Perpajakan}

Perseroan Terbatas (PT) merupakan subjek pajak badan sebagaimana dimaksud dalam UU PPh Pasal 2 ayat (1) huruf b. Perseroan Terbatas (PT) wajib mendaftarkan diri untuk memperoleh NPWP. Kewajiban perpajakan PT adalah sebagai pembayar pajak, pemotong dan/atau pemungut pajak sesuai ketentuan peraturan perundang-undangan perpajakan, termasuk melaporkan SPT Tahunan PPh Badan.

\section{B. Aspek Pajak Penghasilan atas Penyertaan Modal}

Penyetoran modal kepada PT baru berupa tanah dari PT X terutang PPh Final dan berupa dana dari PT Y kepada KSO tidak terutang PPh.

\begin{tabular}{|c|c|r|r|}
\hline Keterangan & PT X & PT Y & PT baru \\
\hline Pajak Penghasilan & 3.120 .181 .531 & & 0 \\
\hline
\end{tabular}

Gambar 6. PPh Setoran Modal kepada PT baru

Sumber: DATA DIOLAH

\section{Aspek Pajak Penghasilan atas Pembangunan Properti}

Atas penggunaan jasa konstruksi tersebut PT baru wajib melakukan pemotongan PPh sesuai dengan ketentuan yang berlaku. PPh Final yang dipotong tersebut akan mengurangi jumlah pembayaran dari PT baru kepada pihak penyedia jasa konstruksi.

\section{Aspek Pajak Penghasilan atas Penjualan Properti}

Berdasarkan data-data penjualan unit perumahan yang telah disebutkan diatas maka berikut ini adalah penghitungan jumlah penghasilan atas penjualan unit perumahan yang diterima oleh PT baru dan PPh Final-nya:

\begin{tabular}{|l|lr|}
\hline \multicolumn{1}{|c|}{ Keterangan } & \multicolumn{2}{c|}{ PT baru } \\
\hline Jumlah Unit & \multicolumn{2}{c|}{2.094 unit } \\
\hline Harga Jual/ Unit & $\mathrm{Rp}$ & 495.000 .000 \\
\hline Total Penjualan & $\mathrm{Rp}$ & 1.036 .530 .000 .000 \\
\hline Total PPh Final 5\% & $\mathrm{Rp}$ & 51.826 .500 .000 \\
\hline
\end{tabular}

Gambar 7. Penghasilan Penjualan Properti dan PPh

Sumber: DATA DIOLAH

\section{E. Aspek Pajak Penghasilan atas Laba Bersih}

Atas Laba Bersih PT baru akan dikenakan pajak penghasilan berdasarkan UU PPh Pasal 16 ayat (1) dan Pasal 17 ayat (2a). Dikarenakan penghasilan PT baru berupa penjualan perumahan telah dikenakan PPh Final, maka tidak terdapat pajak penghasilan 
badan yang terutang sebagaimana. Beban pajak penghasilan yang mengurangi laba bersih PT baru adalah PPh Final yang telah dibayarkan atas penjualan perumahan.

F. Aspek Pajak Penghasilan atas Dividen

Atas laba bersih yang diterima PT baru setelah dikurangi penyisihan untuk cadangan akan dibagikan kepada pemegang saham yaitu PT X dan PT Y dalam bentuk dividen. Kepemilikan saham PT X dan PT Y di PT baru masing-masing adalah 65\% dan 35\%. Maka dividen yang diterima oleh PT $X$ dan PT $Y$ bukan merupakan objek pajak penghasilan dikarenakan berasal dari cadangan laba yang ditahan dan kepemilikan saham pada PT baru melebihi $25 \%$ (dua puluh lima persen).

Berdasarkan seluruh pembahasan diatas dan untuk memperjelas mengenai pembahasan tersebut maka dirangkum dalam bentuk tabel rangkuman hasil pembahasan sebagai berikut:

\begin{tabular}{|l|r|r|r|r|}
\hline \multirow{2}{*}{ Keterangan } & \multicolumn{5}{|c|}{ Alternatif 1 } \\
\cline { 2 - 6 } & \multicolumn{1}{|c|}{ PT X } & \multicolumn{1}{|c|}{ PT Y } & \multicolumn{1}{c|}{ KSO } & \multicolumn{1}{c|}{ Total } \\
\hline PPh atas Penyertaan Modal & 0 & 0 & 0 & 0 \\
\hline PPh atas Pembangunan Properti & 0 & 0 & 0 & 0 \\
\hline PPh atas Penjualan Properti & 33.687 .225 .000 & 18.139 .275 .000 & 0 & 51.826 .500 .000 \\
\hline PPh atas Laba Bersih & 0 & 50.498 .954 & 0 & 50.498 .954 \\
\hline PPh atas Dividen & 0 & 0 & 0 & 0 \\
\hline \multicolumn{1}{|c|}{ Jumlah } & $\mathbf{3 3 . 6 8 7 . 2 2 5 . 0 0 0}$ & $\mathbf{1 8 . 1 8 9 . 7 7 3 . 9 5 4}$ & $\mathbf{0}$ & $\mathbf{5 1 . 8 7 6 . 9 9 8 . 9 5 4}$ \\
\hline
\end{tabular}

Gambar 8. Rangkuman Hasil Pembahasan Alternatif 1 (KSO)

Sumber: DATA DIOLAH

\begin{tabular}{|l|r|r|r|r|}
\hline \multirow{2}{*}{ Keterangan } & \multicolumn{5}{|c|}{ Alternatif 2 } \\
\cline { 2 - 5 } & \multicolumn{1}{|c|}{ PT X } & \multicolumn{1}{|c|}{ PT Y } & \multicolumn{1}{c|}{ PT baru } & \multicolumn{1}{c|}{ Total } \\
\hline PPh atas Penyertaan Modal & 3.120 .181 .531 & 0 & 0 & 3.120 .181 .531 \\
\hline PPh atas Pembangunan Properti & 0 & 0 & 0 & 0 \\
\hline PPh atas Penjualan Properti & 0 & 0 & 51.826 .500 .000 & 51.826 .500 .000 \\
\hline PPh atas Laba Bersih & 0 & 0 & 0 & 0 \\
\hline PPh atas Dividen & 0 & 0 & 0 & 0 \\
\hline Jumlah & $\mathbf{3 . 1 2 0 . 1 8 1 . 5 3 1}$ & $\mathbf{0}$ & $\mathbf{5 1 . 8 2 6 . 5 0 0 . 0 0 0}$ & $\mathbf{5 4 . 9 4 6 . 6 8 1 . 5 3 1}$ \\
\hline
\end{tabular}

Gambar 9. Rangkuman Hasil Pembahasan Alternatif 2 (PT baru)

Sumber: DATA DIOLAH

\section{KESIMPULAN}

Berdasarkan hasil pembahasan diatas maka dapat ditarik kesimpulan sebagai berikut:

1. Kewajiban Perpajakan

a. KSO tidak termasuk dalam pengertian subjek pajak sebagaimana dimaksud dalam UU PPh. Namun KSO tetap wajib mendaftarkan diri untuk memperoleh NPWP. Kewajiban KSO mendaftarkan diri untuk memperoleh NPWP adalah semata-mata hanya untuk memenuhi kewajiban perpajakan sebagai pemotong dan/atau pemungut pajak sesuai ketentuan peraturan perundangundangan perpajakan. Lebih lanjut KSO juga tidak wajib menyampaikan SPT Tahunan PPh Badan. Pengenaan PPh Badan atas penghasilan KSO dikenakan 
pada masing-masing badan anggota KSO sesuai dengan bagian penghasilan yang diterimanya.

b. PT merupakan Wajib Pajak badan dan juga wajib mendaftarkan diri untuk memperoleh NPWP. PT memiliki kewajiban perpajakan sebagai pembayar pajak, pemotong dan/atau pemungut pajak sesuai ketentuan peraturan perundang-undangan perpajakan termasuk menyampaikan SPT Tahunan PPh Badan.

2. Berdasarkan perhitungan yang telah dilakukan maka dapat dihitung jumlah beban pajak penghasilan yang ditanggung oleh PT X, PT Y, KSO maupun PT baru sebagaimana dapat dilihat pada Gambar 8 dan Gambar 9.

Dari kedua gambar tersebut dapat dilihat bahwa alternatif yang akan menghasilkan efisiensi biaya pajak penghasilan yang lebih tinggi adalah alternatif pertama yaitu dengan pembentukan KSO. Perbedaan yang siginifikan dalam penghematan pajak terletak pada PPh atas penyetoran modal berupa tanah dari PT X. Penyetoran modal berupa tanah kepada KSO tidak termasuk dalam pengertian pengalihan hak atas tanah dan/atau bangunan sehingga tidak terutang PPh Final bagi PT X. Sedangkan penyetoran modal berupa tanah kepada PT baru termasuk dalam pengertian pengalihan hak atas tanah dan/atau bangunan sehingga terutang PPh Final bagi PT X.

3. Terdapat beberapa pertimbangan unsur lain atas pemilihan kedua alternatif tersebut selain dari sisi pembayaran pajak penghasilan yaitu:

a. Pengembalian modal yang diinvestasikan

Pengembalian modal yang diinvestasikan akan lebih cepat apabila dilakukan dengan pembentukan KSO dibanding apabila dilakukan pembentukan PT baru. Hal ini dikarenakan bahwa PT wajib menyisihkan jumlah tertentu dari laba bersih setiap tahun buku untuk cadangan sehingga tidak seluruh laba bersih PT dapat dibagikan kepada pemegang saham dalam bentuk dividen. Sedangkan laba bersih KSO langsung dibagikan seluruhnya kepada para anggota KSO sesuai dengan bagian masing-masing.

b. Pemeriksaan Pajak

Kewajiban perpajakan KSO hanya sebagai pemotong dan/atau pemungut pajak sesuai ketentuan peraturan perundang-undangan perpajakan sedangkan kewajiban perpajakan PT baru sebagai pembayar pajak, pemotong dan/atau pemungut pajak sesuai ketentuan peraturan perundang-undangan perpajakan. Dengan demikian dapat disimpulkan bahwa kewajiban perpajakan PT baru lebih luas daripada kewajiban perpajakan KSO sehingga apabila dilakukan pemeriksaan pajak terkait penghapusan NPWP dikarenakan 
adanya pembubaran maka ruang lingkup pemeriksaan atas PT baru akan lebih luas daripada ruang lingkup pemeriksaan atas KSO.

c. Kepastian hukum terhadap pemajakan atas kerjasama operasi Hingga saat ini belum ada perangkat hukum baik dalam UU Pajak, Peraturan Pemerintah maupun Peraturan atau Keputusan Menteri Keuangan yang mengatur tentang pemajakan atas kerjasama operasi atau JO. Yang ada hanyalah surat-surat khusus dari Dirjen Pajak (private rulling) yang merupakan jawaban atas pertanyaan-pertanyaan yang diajukan oleh Wajib Pajak. Surat-surat inilah yang akhirnya dijadikan sebagai acuan hukum yang berlaku bagi Wajib Pajak. Namun demikian terdapat ketidakkonsistenan beberapa Surat Penegasan Dirjen Pajak tentang pemajakan atas JO terutama untuk aspek PPN yang akhinya menimbulkan ketidakpastian. Asas kepastian hukum sangat penting untuk menghindari terjadinya dispute antara fiskus dengan Wajib Pajak atau antar fiskus itu sendiri dalam menafsirkan pemajakan atas JO yang pada akhirnya berpengaruh pada perbedaan dalam perlakuan perpajakannya.

\section{DAFTAR REFERENSI}

Direktur Jenderal Pajak (A. Fuad Rahmany). 2013. Peraturan Direktur Jenderal Pajak Nomor PER-20/PJ/2013: Tata Cara Pendaftaran dan Pemberian Nomor Pokok Wajib Pajak, Pelaporan Usaha dan Pengukuhan Pengusaha Kena Pajak, Penghapusan Nomor Pokok Wajib Pajak dan Pencabutan Pengukuhan Pengusaha Kena Pajak, Serta Perubahan Data dan Pemindahan Wajib Pajak.

Direktur Jenderal Pajak (A. Fuad Rahmany). 2013. Surat Edaran Direktur Jenderal Pajak Nomor SE-30/PJ/2013: Pelaksanaan Pajak Penghasilan Yang Bersifat Final Atas Penghasilan Dari Pengalihan Hak Atas Tanah dan/atau Bangunan Yang Diterima atau Diperoleh Wajib Pajak Yang Usaha Pokoknya Melakukan Pengalihan Hak Atas Tanah dan/atau Bangunan dan Penentuan Jumlah Bruto Nilai Pengalihan Hak Atas Tanah dan/atau Bangunan Oleh Wajib Pajak Yang Melakukan Pengalihan Hak Atas Tanah dan/atau Bangunan.

Direktur Jenderal Pajak (Herry Sumardjito). 2005. Surat Direktur Jenderal Pajak Nomor S - 830/PJ.312/2005: Permohonan Penegasan Pengenaan Pajak.

Direktur Jenderal Pajak (Mochamad Tjiptardjo). 2010. Peraturan Direktur Jenderal Pajak Nomor PER-34/PJ/2010: Bentuk Formulir Surat Pemberitahuan Tahunan Pajak Penghasilan Wajib Pajak Orang Pribadi Dan Wajib Pajak Badan Beserta Petunjuk Pengisiannya.

Direktur Jenderal Pajak (Mochamad Tjiptardjo). 2010. Surat Edaran Direktur Jenderal Pajak Nomor SE - 66/PJ/2010: Penegasan Atas Pelaksanaan Pasal 31E ayat (1) 
Undang-Undang Nomor 7 Tahun 1983 Tentang Pajak Penghasilan Sebagaimana Telah Beberapa Kali Diubah Terakhir Dengan Undang-Undang Nomor 36 Tahun 2008.

Direktur Jenderal Pajak (Wahono). 1989. Surat Direktur Jenderal Pajak Nomor S 323/PJ.42/21989: Masalah Perpajakan Bagi Joint Operation.

Fitriandi, P., Y. Aryanto, \& A.P. Priyono. 2010. Kompilasi Undang-Undang Perpajakan Terlengkap 2010. Jakarta: Salemba Empat.

Ikatan Akuntan Indonesia. 1997. Pernyataan Standar Akuntansi Keuangan (PSAK) Nomor 39: Akuntansi Kerjasama Operasi.

Ikatan Akuntan Indonesia. 2011. Pernyataan Pencabutan Standar Akuntansi Keuangan ED PPSAK Nomor 11 Pencabutan PSAK 39: Akuntansi Kerjasama Operasi.

Menteri Keuangan (Agus D.W. Martowardjojo). 2013. Peraturan Menteri Keuangan Republik Indonesia Nomor 17/PMK.03/2013: Tata Cara Pemeriksaan.

Menteri Keuangan (Mar'ie Muhammad). 1994. Keputusan Menteri Keuangan Republik Indonesia Nomor 635/KMK.04/1994: Pelaksanaan Pembayaran dan Pemungutan Pajak Penghasilan Atas Penghasilan Dari Pengalihan Hak Atas Tanah dan/atau Bangunan.

Menteri Keuangan (Sri Mulyani Indrawati). 2008. Peraturan Menteri Keuangan Republik Indonesia Nomor 243/PMK.03/2008: Perubahan Kedua Atas Keputusan Menteri Keuangan Republik Indonesia Nomor 635/KMK.04/1994 Tentang Pelaksanaan Pembayaran dan Pemungutan Pajak Penghasilan Atas Penghasilan Dari Pengalihan Hak Atas Tanah dan/atau Bangunan.

Moleong, L.J. 2013. Metodologi Penelitian Kualitatif. Bandung: PT Remaja Rosdakarya.

Muljono, Djoko. 2009. Tax Planning: Menyiasati Pajak dengan Bijak. Yogyakarta: CV Andi Offset.

Pohan, C.A. 2011. Optimizing Corporate Tax Management: Kajian Perpajakan dan Tax Planning-nya Terkini. Jakarta: PT Bumi Aksara.

Pohan, C.A. 2009. Aspek Pajak Joint Operation dan Kepastian Hukumnya. Indonesian Tax Review. (Vol II/Edisi 13/2009): 29-40.

Presiden Republik Indonesia (Soeharto). 1994. Peraturan Pemerintah Republik Indonesia Nomor 48 Tahun 1994: Pembayaran Pajak Penghasilan Atas Penghasilan Dari Pengalihan Hak Atas Tanah dan/atau Bangunan.

Presiden Republik Indonesia (Dr.H. Susilo Bambang Yudhoyono). 2007. Undang-Undang Republik Indonesia Nomor 40 Tahun 2007 Tentang Perseroan Terbatas.http://aria.bapepam.go.id/reksadana/files/regulasi/UU\%2040\%202007 \%20Perseroan\%20Terbatas.pdf diakses tanggal 15 Juli 2014.

Presiden Republik Indonesia (Dr.H. Susilo Bambang Yudhoyono). 2008. Peraturan Pemerintah Republik Indonesia Nomor 71 Tahun 2008: Perubahan Ketiga Atas Peraturan Pemerintah Nomor 48 Tahun 1994 tentang Pembayaran Pajak Penghasilan Atas Penghasilan Dari Pengalihan Hak Atas Tanah dan/atau Bangunan.

Presiden Republik Indonesia (Dr.H. Susilo Bambang Yudhoyono). 2008. Peraturan Pemerintah Republik Indonesia Nomor 51 Tahun 2008: Pajak Penghasilan Atas Penghasilan Dari Usaha Jasa Konstruksi. 
Presiden Republik Indonesia (Dr.H. Susilo Bambang Yudhoyono). 2009. Peraturan Pemerintah Republik Indonesia Nomor 40 Tahun 2009: Perubahan Atas Peraturan Pemerintah Republik Indonesia Nomor 51 Tahun 2008 Tentang Pajak Penghasilan Atas Penghasilan Dari Usaha Jasa Konstruksi.

Presiden Republik Indonesia (Dr.H. Susilo Bambang Yudhoyono). 2010. Peraturan Pemerintah Republik Indonesia Nomor 94 Tahun 2010: Penghitungan Penghasilan Kena Pajak dan Pelunasan Pajak Penghasilan Dalam Tahun Berjalan.

Sarosa, Samiaji. 2012. Penelitian Kualitatif: Dasar-Dasar. Jakarta: PT Indeks.

Tambunan, Ruston. 2007. Ketidakpastian atas Perlakuan Perpajakan Joint Operation (JO) dalam Bidang Usaha Jasa Konstruksi. http://www.ortax.org/ortax/?mod=issue\& page=show\&id=18\&q=\&hlm=5 diakses tanggal 15 Juli 2014.

Yin, R.K. 2013. Studi Kasus: Desain \& Metode. Jakarta: PT RajaGrafindo Persada. 